\title{
Żydowskie dziedzictwo religijne w koncepcji krajobrazu konfliktu Materialne świadectwa Zagłady i działań zbrojnych na przykładzie Nowego Cmentarza Żydowskiego w Łodzi
}

\author{
Jewish Religious Heritage in the Conception of the Landscape of Conflict: \\ Material Testimonies of the Holocaust and Military Operations \\ on the Example of the New Jewish Cemetery in Łódź
}

\begin{abstract}
Aвstract: The landscape of conflict is a conception which has recently attracted a lot of attention in landscape studies. It chiefly inspires studies that represent the field of the archeology of the present, thus constituting one of the keys to reading? history from the structures of the surrounding cultural landscape. This article proposes to extend the conception of the landscape of conflict into the discourse about Jewish material religious heritage. Attention paid by the humanist to materiality reveals new contexts of the Holocaust, including its non-human, landscape representations. Here, an adaptation of the conception in the studies of Jewish religious heritage has been carried out on the example of research conducted in the vicinity of the New Jewish Cemetery in Łódź. This article presents the results of studies of chosen elements of this landscape of conflict, elements which, along with other functions, constitute the physical fact of the gravestones of the necropolis. The research drawn upon was gathered using the methods of non-invasive field documentation; the analysis involves the comparisons of photogrammetric and teledetection data, including point clouds obtained by laser scanning and aerial photographs. These were the basis for the spatial models of the structures of material heritage under consideration, which constitute historical palimpsests, and for the identification of the elements of this landscape of conflict.
\end{abstract}

KEY WORDS: archaeology of the contemporary past, landscape studies, LiDAR, materiality turn, Jewish cemeteries, World War Two 


\section{Wprowadzenie}

Żydowskie obiekty religijne znajdujące się na terenie współczesnej Polski są dziedzictwem kulturowym, które poddawane było i w wielu przypadkach nadal podlega intensywnym przekształceniom, dotyczącym zarówno ich struktur materialnych, jak i wartości niematerialnych. W sposób szczególny dotyczy to cmentarzy, brutalnie zniszczonych w czasie drugiej wojny światowej, która stanowi pierwszy, główny etap, nazywany w literaturze okresem „zagłady cmentarzy żydowskich" . Znamienne jest także piętno działań powojennych, dokonywanych zarówno z pobudek prywatnych, jak i podyktowanych politycznie oraz usankcjonowanych prawnie, inicjowanych między innymi uchwałami władz samorządowych. Powojenne niszczenie naziemnych struktur cmentarzy oraz ich przekształcanie w nekropolie innych wyznań wpisuje się w ideę nekronacjonalizmu, zgodnie z którą groby przodków i mogiły poległych konstytuują tożsamość lokalną oraz przypieczętowują przynależność ziemi do określonych grup ją zamieszkujących ${ }^{2}$. W związku z tym, na przykład wraz ze zmianą przynależności geopolitycznej terytorium i/lub z przerwaniem ciągłości kulturowej, groby, będące swego rodzaju dawnymi symbolami narodowymi, umacniającymi tożsamość wspólnotową, są często usuwane na znak braku identyfikacji z wcześniejszą przynależnością polityczną lub strukturą społeczno-kulturową. Tego rodzaju procesami na terenie Polski po 1945 roku objęte zostały między innymi cmentarze żydowskie na skutek zagłady lokalnych wspólnot wyznaniowych, które nimi rozporządzały.

Ponadto, w przypadku żydowskich miejsc pochówku dewastacja jest zjawiskiem szczególnie złożonym, zwłaszcza $\mathrm{z}$ uwagi na kontrowersje związane $\mathrm{z}$ reużytkowaniem przestrzeni cmentarzy (na przykład resakralizacją ${ }^{3}$ - zamianą w cmentarze komunalne lub wojskowe, desakralizacją - przekształcaniem w place, parki, parkingi, pola orne, tereny przeznaczone pod budownictwo itp.)

${ }^{1}$ To ujęcie Krzysztofa Bielawskiego. Autor ten wskazuje nawet szerszą cezurę: lata 1933-1945, biorąc pod uwagę akty dewastacji dokonywane po dojściu Hitlera do władzy w latach 30 . XX wieku, którymi dotknięte zostały obiekty położone na terenie Dolnego i części Górnego Śląska. Por. K. Bielawski: Zagłada cmentarzy żydowskich. Warszawa 2020, s. 23-24.

2 Por. E. Domańska: Cmentarze jako przedmiot historii ratowniczej (rescue history). W: Ziemia skrywa kości. Zapomniane krajobrazy pamięci - cmentarze protestanckie w Wielkopolsce po 1945 roku. Red. J. Kołacki, I. Skórzyńska. Poznań 2017, s. 34.

${ }^{3}$ Resakralizacja - przekształcenie cmentarza wyznaniowego polegające na kontynuacji jego funkcji grzebalnej poprzez adaptowanie jego przestrzeni na nekropolię innowierczą, komunalną bądź wojskową. W przypadku cmentarzy np. wyznania rzymskokatolickiego grób po upłynięciu odpowiedniego czasu można ponownie wykorzystać pod nowy pochówek, co jest niedopuszczalne w judaizmie, por. A. Majewska: Continuity and Decline. Temporal Expression of Denominational Cemeteries in Contemporary Times. „Acta Universitatis Lodziensis. Folia Archaeologica” 2019, nr 34, s. 73. 
oraz wtórnym wykorzystywaniem nagrobków, między innymi jako surowca budowlanego ${ }^{4}$. Profanacja przestrzeni grzebalnej w przypadku cmentarza żydowskiego obejmuje znacznie szerszy zakres aktów, które w kontekście wykładni różnych odłamów judaizmu (zwłaszcza ortodoksyjnego) uznawane są za rażące, naruszające miejsce spoczynku zmarłych. Należy do nich niemal wszelka ingerencja w grunt na obszarze grzebalnym, co zostało podkreślone przez Krzysztofa Bielawskiego - „za destrukcję dodatkowo uznaje się [...] między innymi badania archeologiczne, odkopywanie lub wtórne wkopywanie nagrobków, usuwanie systemów korzeniowych drzew i krzewów"5.

Cmentarze są w przestrzeni jednym z punktów węzłowych, kotwiczących pamięć dotyczącą lokalnych wspólnot żydowskich. Stanowią ślady ich życia oraz dawnego współtworzenia przez nie społeczności miast i niewielkich miejscowości, ale przede wszystkim przypominają o śmierci oraz Zagładzie, silnie naznaczone wydarzeniami traumatycznymi, często jako miejsca egzekucji i pochówku ofiar. Z tego względu dotyczące ich przekształcenia zachodzące w XX i XXI wieku na skutek społecznego „przetwarzania” tych obiektów w wymiarze materialnym i semiotycznym skłaniają do postawienia wielu pytań badawczych powiązanych $\mathrm{z}$ funkcjonowaniem tych miejsc w ramach różnych typów konfliktów. Tematyka ta znajduje odzwierciedlenie we współczesnych badaniach, między innymi w ramach archeologii Holokaustu ${ }^{6}$. Wciąż jednak istnieje luka w analizach z zakresu przekształceń żydowskiego dziedzictwa religijnego na skutek przebiegu różnego rodzaju konfliktów, w tym potrzeba ściślejszego wyodrębnienia i klasyfikacji charakterystycznych zjawisk oraz procesów dotyczących cmentarzy żydowskich, zwłaszcza w szerszym kontekście społecznym i przestrzennym. W badaniach odnoszących się do ziem polskich najbardziej wnikliwą pracą na ten temat, porządkującą zjawisko dewastacji cmentarzy żydowskich według kryterium chronologicznego, jest syntetyczne opracowanie autorstwa Bielawskiego ${ }^{7}$.

Różnorodność zjawisk powodujących destruktywne przekształcenia cmentarzy żydowskich na terenie Polski i wynikające z tego pytania o ich funkcjonowanie w środowisku społeczno-kulturowym stanowiły impuls do zaproponowania nowego ujęcia, służącego analizie procesów związanych z destrukcją obiektów, zwłaszcza w kontekście identyfikacji i interpretacji ich materialnych skutków. Podjęto tu próbę rozpoznania tego rodzaju zjawisk w ramach koncepcji krajobrazu konfliktu, która pojawiła się we współczesnych studiach humanistycznych w obrębie archeologii czasów współczesnych. Koncepcja ta, szerzej omówiona w części odnoszącej się do teoretycznej konceptualizacji zrealizowanych

${ }^{4}$ Zob. Ł. Baksik: Macewy codziennego użytku. Wołowiec 2012.

${ }^{5}$ K. Bielawski: Zagłada cmentarzy..., s. 12.

${ }^{6}$ Por. C.S. Colls: Holocaust Archaeologies. Approaches and Future Directions. London 2015; Taż: Holocaust Archaeology: Archaeological Approaches to Landscapes of Nazi Genocide and Persecution. "Journal of Conflict Archaeology" 2012, Vol. 7, Issue 2, s. 70-104.

7 Zob. K. Bielawski: Zagłada cmentarzy... 
badań, skłania się przede wszystkim ku wyodrębnianiu (również na zasadzie palimpsestu) elementów i atrybutów przestrzeni stanowiących świadectwo działań wojennych, ale i różnego rodzaju sytuacji konfliktowych. Posłużenie się nią w studiach dotyczących cmentarzy żydowskich pokazuje możliwość podejmowania nowych kierunków analiz ich przestrzeni, zwłaszcza w celu zbadania słabo rozpoznanych wątków z ich historii, w szczególności w związku z zastosowaniem metod nieinwazyjnej dokumentacji powierzchniowej, w ramach których wykorzystuje się między innymi narzędzia GIS i technologię LiDAR.

Jako część aplikacyjną, w kontekście podjętych wcześniej rozważań teoretycznych, przedstawiono studium badawcze dotyczące Nowego Cmentarza Żydowskiego w Łodzi. Na przykładzie studium przestrzeni tego wyjątkowego obiektu dziedzictwa kulturowego ukazano propozycję rozszerzenia możliwości analizy i interpretacji obszaru historycznego cmentarza żydowskiego w humanistycznym dyskursie dotyczącym żydowskiego dziedzictwa kulturowego i krajobrazowych świadectw Zagłady.

\section{Krajobraz konfliktu - propozycja konceptualizacji pojęcia w studiach nad żydowskim dziedzictwem religijnym}

Koncepcja krajobrazu konfliktu odgrywa szczególnie dużą rolę w badaniach realizowanych w ramach archeologii współczesności, skupionej w wysokim stopniu na materialnych świadectwach pierwszej i drugiej wojny światowej, a także różnego rodzaju paramilitarnych oraz wojskowych działaniach powojennych ${ }^{8}$. Obok studiów na temat miejsc zbrodni prowadzone są również dotyczące wojennych przekształceń struktur krajobrazowych, na przykład obiektów wojskowych, w tym fortyfikacji polowych oraz między innymi śladów bombardowań tzw. landscape of bombing oraz bombsite archaeology ${ }^{9}$. Do prekursorów analiz z zakresu krajobrazu konfliktu należą Nicholas J. Saunders oraz Neil Faulkner. Szczególną uwagę poświęcają oni reliktom dwudziestowiecznych konfliktów

${ }^{8}$ W Polsce m.in.: Archeologia totalitaryzmu. Ślady represji 1939-1956. Red. O. Ławrynowicz, J. Żelazko. Łódź 2015; Katyń w świetle badań terenowych 1994-1995. Red. M. Głosek. Toruń 2003; D. Kobiałka, M. Frąckowiak, K. Kajda: Tree Memories of the Second World War: a Case Study of Common Beeches from Chycina, Poland. "Antiquity" 2015, Vol. 89, Issue 345, s. 683-696; A. Kola: Archeologia zbrodni. Oficerowie polscy na cmentarzu ofiar NKWD w Charkowie. Toruń 2005.

9 Zob. G. Moshenska: Resonant Materiality and Violent Remembering: Archaeology, Memory and Bombing. "International Journal of Heritage Studies" 2009, Vol. 15, Issue 1, s. 44-56; D.G. Passmore, S. Harrison, D.C. Tunwell: Second World War Conflict Archaeology in the Forests of North-west Europe. "Antiquity" 2014, Vol. 88, Issue 342, s. 1275-1290. 
zbrojnych ${ }^{10}$. Ponadto są inicjatorami rozszerzania perspektywy badawczej krajobrazu konfliktu także o kontekst społeczny, między innymi zagadnienia pamięcioznawcze. W związku z tym istotną rolę w ich koncepcji, poza obiektywnymi, materialnymi świadectwami konfliktów, odgrywają również pamięć świadków wydarzeń oraz pamięć wspólnotowa, która podlega transmisji kulturowej, kształtując między innymi niematerialne dziedzictwo kulturowe oraz wiedzę o dziedzictwie materialnym ${ }^{11}$. Należy nadmienić, że kwestie powiązań między działaniami zbrojnymi, społecznościami, kulturą materialną i krajobrazem są $\mathrm{w}$ różnym wymiarze poruszane także $\mathrm{w}$ studiach $\mathrm{z}$ zakresu historycznych krajobrazów konfliktu ${ }^{12}$.

Krajobraz konfliktu sensu stricto, w realnej (materialnej) perspektywie badawczej, jest zatem przestrzenią, gdzie doszło do nagromadzenia obiektów ukształtowanych bądź przekształconych w wyniku działań związanych z przebiegiem konfliktu zbrojnego. Dotyczy to w szczególności elementów łączących się z "teatrem działań wojennych”, do których należą między innymi: miejsca starć zbrojnych i pola bitewne, fortyfikacje polowe, obozy koncentracyjne i jenieckie, cmentarze wojenne. Taka koncepcja krajobrazu konfliktu dominowała dotychczas w analizach z zakresu archeologii konfliktów zbrojnych ${ }^{13}$.

Stosunkowo łatwo wyodrębnić przekształcenia stanowiące bezpośredni skutek działań zbrojnych, do których należą na przykład: ślady po ostrzałach, okopy zlokalizowane na terenach cmentarzy, zmiany $\mathrm{w}$ budowlach spowodowane detonacją ładunków wybuchowych etc. W przypadku żydowskich obiektów religijnych dokonane $\mathrm{w}$ ich obrębie zniszczenia drugowojenne stanowią przede wszystkim świadectwa przeprowadzonej przez Niemców eksterminacji narodu żydowskiego. Na cmentarzach żydowskich znajdują się między innymi zbiorowe mogiły, których rozpoznanie pozostaje o tyle utrudnione, że zgodnie z poszanowaniem zasad judaizmu może być dokonane wyłącznie metodami nieinwazyjnymi, nienaruszającymi struktury gruntu, które pozwalają jedynie na wstępną identyfikację obiektów.

Pojęcie „krajobraz konfliktu” posiada wiele innych egzemplifikacji i odnosi się nie tylko do działań zbrojnych, ale też krajobrazowych świadectw innego

${ }^{10}$ M.in.: N.J. Saunders: Trench Art: A Brief History and Guide. Philadelphia 2001; Tenże: Killing Time. Archaeology and the First World War. Stroud 2007; Tenże, N. Faulkner: Fire on the Desert: Conflict Archaeology and the Great Arab Revolt in Jordan, 1916-18. "Antiquity" 2010, Vol. 84, Issue 324, s. 514-527.

${ }^{11}$ Por. P.A. Schackel: Archaeology, Memory, and Landscapes of Conflicts. "Historical Archaeology" 2003, Vol. 37, Issue 3, s. 3; J. Szacki: Dylematy historiografii idei oraz inne szkice i studia. Warszawa 1991, s. 240-241; A.P. Wejland: Pojęcia podstawowe. W: Miejsca pamięci i miejsca zapomnienia. Interdyscyplinarne badania na Jurze Krakowsko-Częstochowskiej. Raport $z$ badań. T. 1: Wprowadzenie metodologiczne. Red. A.P. Wejland, O. Ławrynowicz. Łódź 2016, s. 38.

${ }^{12}$ Np. O.H. Creighton, D.W. Wright: The Anarchy. War and Status in 12th-Century Landscapes of Conflict. Liverpool 2016.

${ }^{13}$ Por. J. Schofield: Combat Archaeology: Material Culture and Modern Conflict. London 2005. 
rodzaju konfliktów, między innymi: rasowych, klasowych ${ }^{14}$, dotyczących użytkowania przestrzeni ${ }^{15}$. Potrzebę i zasadność rozszerzania pojęcia krajobrazu konfliktu poza aspekty militarne zauważa wielu badaczy, między innymi realizujących $\mathrm{w}$ tym zakresie projekty interdyscyplinarne ${ }^{16}$. Krajobraz konfliktu wychodzi w nich poza ramy krajobrazu fizycznego i, jak podaje Łukasz Banaszek: „[...] otrzymuje zróżnicowane znaczenia, subiektywnie odczytywane przez antagonistycznie nastawione grupy. W konsekwencji konstytuowany jest krajobraz rywalizacji/konfliktu (ang. contested landscape), w którym ścierają się wrogie/opozycyjne względem siebie ideologie i wartości"17.

Ralf Dahrendorf słusznie stwierdził, że „w każdym społeczeństwie i w każdym momencie występują niezgoda i konflikt - konflikt społeczny jest wszechobecny"18. Pozostaje zatem owe kwestie sporne zidentyfikować i zinterpretować. Nie jest to trudne, jeśli spojrzeć na losy obiektów dziedzictwa religijnego, którym towarzyszyły bądź towarzyszą różnorodne polemiki, na skutek czego stają się one obiektami konfliktu bądź elementami przestrzeni konfliktowych. Konflikty społeczne mogą mieć różnorodne podłoże: etniczne, narodowościowe, religijne, ekonomiczne, polityczne, ideologiczne bądź personalne ${ }^{19}$.

Krajobraz konfliktu sensu largo jest więc krajobrazem, w którym występuje nagromadzenie obiektów:

- stanowiących pokłosie konfliktów zbrojnych (zarówno autonomicznych obiektów genetycznie związanych z konfliktem, jak i przekształceń dokonywanych w innych, genetycznie niezwiązanych z konfliktem składnikach krajobrazu);

- będących przedmiotem konfliktu/sporu rozumianego jako konflikt społeczny (także religijny, etniczny, narodowościowy, ideologiczny etc., niecharakteryzujący się ekspresją zbrojną).

${ }^{14}$ Por. J.A. Delle, P. Heaton: The Hector Backbone: A Quiescent Landscape of Conflict. "Historical Archaeology" 2003, Vol. 37, Issue 3, s. 94.

${ }^{15}$ Zob. D. Jensen, T. Baird, G. Blank: New Landscapes of Conflict: Land-use Competition at the Urban-rural Fringe. "Landscape Research" 2019, Vol. 44, Issue 4, s. 418-429.

${ }^{16}$ M.in. N.J. Saunders et al.: Conflict Landscapes of the Soča/Isonzo Front, 1915-2013: Archaeological-Anthropological Evaluation of the Soča Valley, Slovenia. „Arheo. Arheološka obvestila. Glasilo Slovenskega arheološkega društva" 2013, 30, s. 47-66.

${ }^{17}$ Ł. Banaszek: Badania archeologiczne w ramach projektu „Sztutowo czy Stutthof? Oswajanie krajobrazu kulturowego". W: Sztutowo czy Stutthof? Oswajanie krajobrazu kulturowego. Red. Ł. Banaszek, M. Wosińska. Poznań-Sztutowo 2011, s. 27.

${ }_{18}$ R. Dahrendorf: Teoria konfliktu w społeczeństwie przemysłowym. W: Elementy teorii socjologicznych. Red. W. Dereczyński, A. Jasińska-Kania, J. Szacki. Warszawa 1975, s. 431-432; por. także: P.T. Coleman et al.: Navigating the Landscape of Conflict: Applications of Dynamical Systems Theory to Addressing Protracted Conflict. In: The Non-linearity of Peace Processes. Theory and Practice of Systemic Conflict Transformation. Eds. D. Körppen, N. Ropers, H.J. Giessmann. Opladen 2011, s. 39.

${ }_{19}$ Por. M. Budyta-Budzyńska: Socjologia narodu i konfliktów etnicznych. Warszawa 2010, s. $222-223$. 
Prowadzenie badań nad społecznymi krajobrazami konfliktu w odniesieniu do żydowskich obiektów religijnych, takich jak między innymi cmentarze, pociąga za sobą przede wszystkim pytania o identyfikację aktorów konfliktów, których materialne skutki można zaobserwować w poddawanych analizie przestrzeniach. Ma to kluczowe znaczenie przede wszystkim $w$ identyfikacji i interpretacji następstw konfliktów zachodzących w okresie powojennym, w którym ze sprawstwa w aktach na przykład dewastacji dokonywanej w obrębie cmentarzy wyłączony zostaje niemiecki okupant.

Ponieważ koncepcja krajobrazu konfliktu z uwagi na swoją genezę jest ściśle powiązana przede wszystkim z metodyką badań archeologicznych, jej zastosowanie $\mathrm{w}$ studiach nad żydowskim dziedzictwem religijnym polega głównie na identyfikacji oraz interpretacji fizycznych skutków konfliktów w strukturze cmentarzy i budynków. $Z$ tego względu zasadniczym elementem aplikacji koncepcji $\mathrm{w}$ badaniach $\mathrm{z}$ tego zakresu jest wykorzystanie metod nieinwazyjnej prospekcji terenowej. Obejmują one w zależności od specyfikacji obiektu między innymi: opis fizykalny oraz dokumentację fotograficzną i techniczno-rysunkową materialnych śladów przebiegu konfliktów, a także inne techniki pozwalające w sposób nieinwazyjny (w szczególności nienaruszający gruntu cmentarzy) zidentyfikować składowe krajobrazu konfliktu. Wykorzystywane w tym celu mogą być na przykład metody geofizyczne, jak pomiary przy użyciu georadaru (przydatne do wstępnej identyfikacji mogił zbiorowych w przestrzeni cmentarzy), techniki GIS - zwłaszcza związane z opracowywaniem planigrafii cmentarzy oraz przetwarzaniem szczegółowych wysokościowych danych pomiarowych (na przykład uzyskanych w wyniku lotniczego skanowania laserowego).

\section{Studium przypadku - Nowy Cmentarz Żydowski w Łodzi}

\section{Metodyka badań}

Analizy empiryczne przedstawione $\mathrm{w}$ opracowaniu oparto na wynikach badań studialnych przeprowadzonych w 2018 roku na terenie Nowego Cmentarza Żydowskiego w Łodzi. Objęły one prospekcję powierzchniową mającą na celu identyfikację w strukturze morfogenetycznej cmentarza obiektów będących efektem bądź noszących ślady działań zbrojnych oraz stanowiących świadectwa Zagłady.

Materialne skutki dwudziestowiecznych konfliktów zbrojnych zarejestrowane w wyniku kartowania terenowego przeprowadzonego na cmentarzu żydowskim w Łodzi poddano następnie analizom szczegółowym, konstruując między innymi cyfrowe modele 3D umożliwiające wyjaśnienie powiązań przestrzennych 
między zinwentaryzowanymi elementami. W studium zintegrowano wyniki badań archeologicznych z systemem informacji geograficznej, co z powodzeniem wykorzystywane jest $\mathrm{w}$ innych badaniach $\mathrm{z}$ zakresu archeologii XX wieku ${ }^{20}$. $\mathrm{W}$ celu przestrzennego zobrazowania zarejestrowanych obiektów opracowano pochodne $\mathrm{z}$ lotniczego skanowania laserowego, wykonanego $\mathrm{w}$ ramach projektu ISOK $^{21}$. Są to szczegółowe dane dotyczące ukształtowania powierzchni gruntu, których wykorzystanie w ramach studiów nad dziedzictwem kulturowym jest współcześnie bardzo popularne z uwagi na przydatność podczas wstępnej identyfikacji stanowisk archeologicznych oraz w celu przybliżenia cech morfologicznych obiektów już rozpoznanych.

$\mathrm{W}$ analizach zastosowano zaczerpnięte $\mathrm{z}$ metodyki studiów historycznych podejście retrogresywne, według którego badacz, wychodząc od czasów późniejszych, dokonuje charakterystyki wcześniejszych etapów funkcjonowania między innymi obiektów i jednostek osadniczych ${ }^{22}$. Podstawą prowadzenia tego rodzaju analiz są materiały referencyjne służące analizie porównawczej, do których należą aktualne i archiwalne opracowania kartograficzne, fotografie lotnicze, wyniki prospekcji terenowych. Dysponując zdjęciem lotniczym obszaru badań $\mathrm{z}$ okresu drugiej wojny światowej i współczesną ortofotomapą terenu, wykonano analizę komparatystyczną obrazowań z zastosowaniem narzędzi GIS.

\section{Wyniki prospekcji terenowej Dyskusja}

Pierwszych pochówków na terenie Nowego Cmentarza Żydowskiego w Łodzi dokonano w listopadzie $1891 \mathrm{roku}^{23}$, obiekt posiada więc zarówno pierwszo-, jak i drugowojenną historię. Niektóre z przekształceń zarejestrowanych podczas prospekcji terenowej powiązano tutaj właśnie z okresem Wielkiej Wojny, kiedy podczas bitwy łódzkiej w ogniu walk znalazła się również nekropolia żydowska $^{24}$. Czas pierwszej wojny światowej należał do „najbardziej katastrofalnych w dziejach Łodzi, zarówno w wymiarze gospodarczym, jak i demograficznym”,

${ }^{20}$ Zob. T.J. Nolan: Geographic Information Science as a Method of Integrating History and Archaeology for Battlefield Interpretation. "Journal of Conflict Archaeology" 2009, Vol. 5, Issue 1, s. $81-104$.

${ }^{21}$ ISOK - Internetowy System Osłony Kraju, w ramach którego zrealizowano m.in. pomiary lotniczego skanowania laserowego terenu Polski. Ich wyniki udostępnione w domenie publicznej mogą być wykorzystywane np. na potrzeby badań archeologicznych.

${ }^{22}$ Por. S. Arnold: Geografia historyczna Polski. Warszawa 1951, s. 57; O. Karsvall: Retrogressiv metod. En översikt med exempel från historisk geografi och agrarhistoria. „Historisk Tidskrift” 2013, 133 (3), s. 411-435.

${ }^{23}$ Zob. E. Wiatr: Historia cmentarza. W: Monumenta et Memoria. Cmentarz żydowski $w$ Łodzi. Red. L. Hońdo. Łódź 2016, s. 11.

${ }^{24}$ Por. A. Stawiszyńska: Łódź w latach I wojny światowej. Oświęcim 2016, s. 193. 
między innymi z powodu odpływu ludności robotniczej25. Jeśli chodzi o ludność pochodzenia żydowskiego, to przebieg działań wojennych wpłynął zwłaszcza na możliwości prowadzenia działalności religijnej: ograniczone zostało sprawowanie kultu, między innymi na skutek poważnego uszkodzenia synagogi znajdującej się przy ul. Wolborskiej, doszło do naruszenia zasad rytualnych w wyniku polityki niemieckich władz okupacyjnych. Pojawiły się także, będące następstwem ogólnego zubożenia ludności, problemy finansowe wpływające na ograniczenie funkcjonowania gminy wyznaniowej ${ }^{26}$.

Dzięki nieinwazyjnej prospekcji powierzchniowej na terenie łódzkiej nekropolii żydowskiej zidentyfikowano między innymi do tej pory nierozpoznane uszkodzenia substancji nagrobkowej, stanowiące przypuszczalnie świadectwo epizodu zbrojnego, jaki odbył się na tym terenie w listopadzie 1914 roku, kiedy w czasie toczonych walk wojska rosyjskie miały zostać ostrzelane przez artylerię niemiecką, a poważne zniszczenia odnotowano między innymi w zabudowaniach $\mathrm{cmentarnych}^{27}$. Zinwentaryzowane uszkodzenia powstały w efekcie ostrzału dokonanego prawdopodobnie z broni maszynowej. Występujące w obrębie kwater "M” oraz „I" ślady po pociskach (ryc. 1, ryc. 2) układają się w powiązane ze sobą sekwencje.

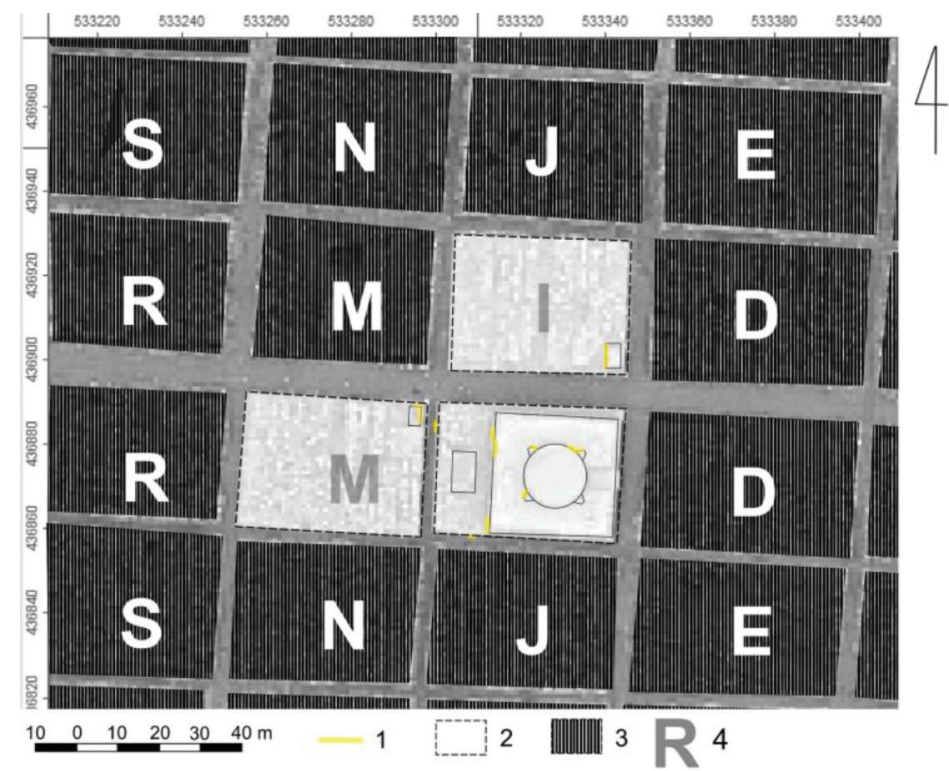

Ryc. 1. Fragment planu cmentarza żydowskiego w Łodzi. Zaznaczono obiekty posiadające ślady ostrzału (1 - umiejscowienie uszkodzeń po ostrzałach, 2 - wyróżnione kwatery, 3 - pozostałe kwatery, 4 - oznaczenie literowe kwater). Opracowanie własne.

\footnotetext{
25 A. Rzepkowski: Ludność Łodzi w okresie I wojny światowej. Łódź 2013, s. 132.

${ }^{26}$ Por. A. Stawiszyńska: Łódź w latach..., s. 193.

${ }^{27}$ Zob. E. Wiatr: Historia cmentarza..., s. 14.
} 

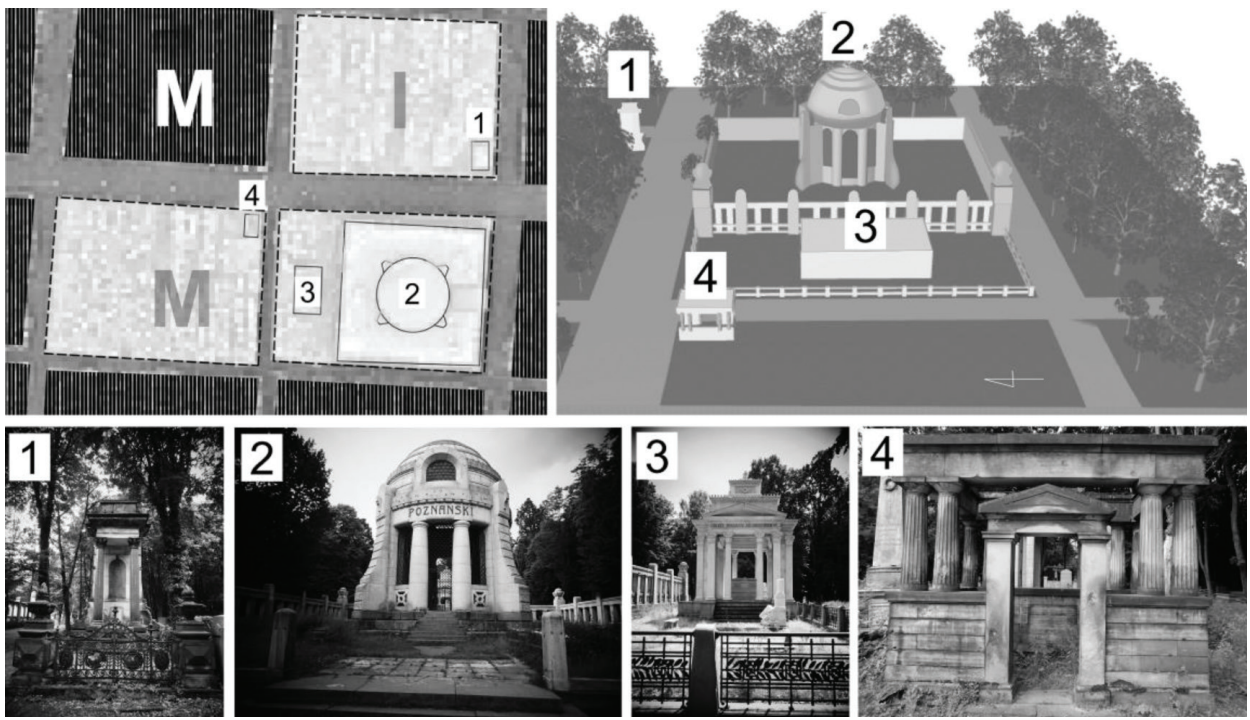

Ryc. 2. Usytuowanie w kwaterach nagrobków i pól grobowych, w obrębie których zidentyfikowano ślady ostrzałów (1 - nagrobek Ignacego Sachsa, 2 - mauzoleum Poznańskich, 3 - mauzoleum Silbersteinów, 4 - nagrobek architektoniczny, nieznane personalia pochowanych). Fotografie i opracowanie własne.

Do śladów tych nawiązuje Mirosław Wojalski ${ }^{28}$, opisując historię cmentarza $\mathrm{w}$ latach pierwszej wojny światowej. Wówczas pewnych szkód na terenie nekropolii miały dokonać pociski artyleryjskie, zwłaszcza w zabudowaniach ulokowanych w części gospodarczej cmentarza. Informacje takie znajdują potwierdzenie w źródłach ikonograficznych opatrzonych datami pierwszowojennymi, ukazujących zniszczenia dokonane w grobowcach ${ }^{29}$. O wojennych dziejach cmentarza Izaak Kersz pisze:

Podczas pierwszej wojny światowej, kiedy 11 listopada 1914 r. wojska niemieckie rozpoczęły operację łódzką, cmentarz znalazł się w ogniu walk. Boje trwały około trzech tygodni. Toczyły się nawet na przedmieściach Łodzi. Artyleria i lotnictwo niemieckie systematycznie ostrzeliwało miasto i jej [sic!] okolice powodując zniszczenie; nie ominęło to cmentarza. We wszystkich budynkach zostały wybite szyby, zniszczono dach Domu Przedpogrzebowego i synagogi, odpadły tynki w pomieszczeniach. Najdotkliwszą szkodą było jednak zniszczenie ogrodzenia cmentarza. [...]

${ }^{28}$ M.Z. Wojalski: Cmentarz żydowski w Łodzi. Łódź 2000, s. 19-20.

${ }^{29}$ Lata 1914-1915 - zob. Nowy Cmentarz Żydowski. Dostępne w Internecie: https://fotopolska. eu/Lodz/b37432,Nowy_cmentarz_zydowski.html?f=1064073-foto [data dostępu: 11.05.2019]; także: E. Wiatr: Historia cmentarza..., s. 14. 
Podczas działań wojennych, gdy front znajdował się blisko cmentarza Gmina Żydowska zamknęła go na kilkanaście tygodni, zmarłych chowano na starym cmentarzu ${ }^{30}$.

Te wyrywkowe i w zasadzie ogólnikowe informacje nie wyjaśniają jednak bezdyskusyjnie dokładnych okoliczności powstania szeregu uszkodzeń po ostrzałach, skumulowanych na dużych grobowcach trzech kwater znajdujących się przy głównej alei nekropolii. Warto wspomnieć, że również 1945 rok wymieniany jest jako czas powstania śladów na kopule mauzoleum Poznańskich podają tak Joanna Podolska i Jacek Walicki ${ }^{31}$. Miały one być skutkiem ostrzału artylerii radzieckiej. Trzeba też zwrócić uwagę na ślady po trafieniach pocisków zlokalizowane $\mathrm{w}$ podobnych miejscach, lecz po dwóch stronach kamiennego ogrodzenia oddzielającego teren otaczający mauzoleum Poznańskich od grobowca Silbersteinów (zob. ryc. 3). Ostrzał nagrobków mógł nastąpić w istocie już w czasie pierwszej wojny światowej, ponieważ dwa z czterech obejść grobowych dotkniętych uszkodzeniami o proweniencji wojennej zostały wzniesione w końcu XIX wieku: nagrobek Ignacego Sachsa i mauzoleum Silbersteinów (1899), a na początku XX wieku - mauzoleum Poznańskich (1902-1905) 32 .

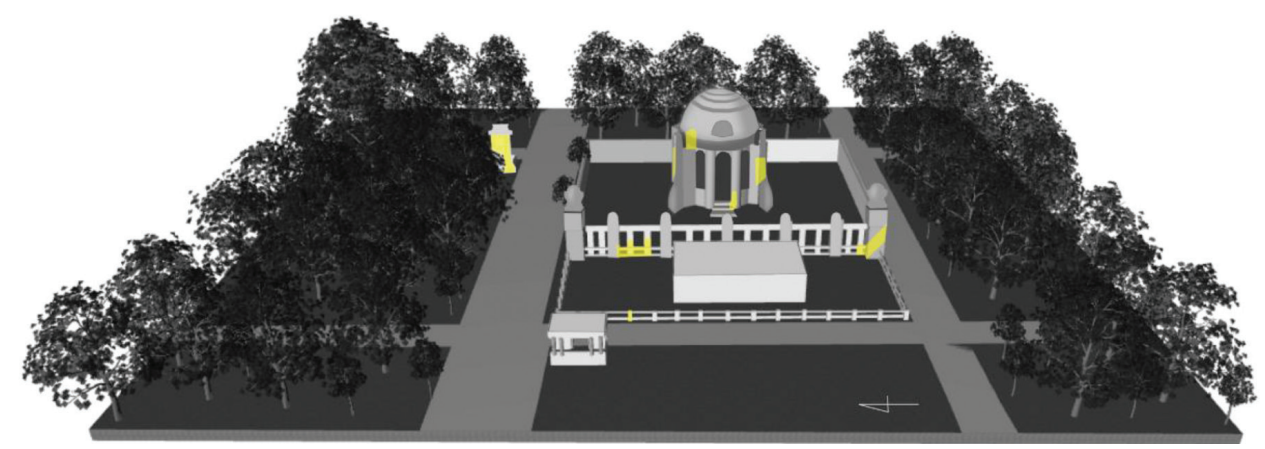

Ryc. 3. Uszkodzenia po ostrzałach na elementach kamiennych kwater „M” oraz „I” cmentarza żydowskiego w Łodzi widoczne od strony zachodniej. Opracowanie własne.

Analiza układu ostrzałów w zachodniej części kwatery „I”, zajmowanej przez założenie przestrzenne mauzoleum Silbersteinów, może wnieść wiele nowych informacji na temat wojennego epizodu, jaki się tam rozegrał (wizualizacja ryc. 4).

Uszkodzenia widoczne na elementach ogrodzenia pola grobowego Silbersteinów występują w jednej linii, co ilustruje ryc. 4. Obserwator najpierw dostrzec może gęstą sieć odprysków poostrzałowych na słupku dookolnego ogrodzenia - w części zachodniej płotu, na czwartym od strony alei głównej słupie

\footnotetext{
${ }^{30}$ I. Kersz: Szkice z dziejów Gminy Żydowskiej oraz cmentarza w Łodzi. Łódź 1996, s. 44.

${ }^{31}$ J. Podolska, J. Walicki: A Guide to the Jewish Cemetery in Łódź. Łódź 1997, s. 43.

32 Por. Monumenta et Memoria...
} 
łącznikowym (ryc. 5). Na pionowych belkowaniach kamiennych, we wschodniej części ogrodzenia pola grobowego Silbersteinów (w jego części wewnętrznej), zarówno na wysokości wymienionego słupa, jak i powyżej niego występują liczne uszkodzenia związane z ostrzelaniem tej przestrzeni. Na tej podstawie można już wyznaczyć częściowy przebieg linii ostrzału w obrębie kwatery „I” (ryc. 4).

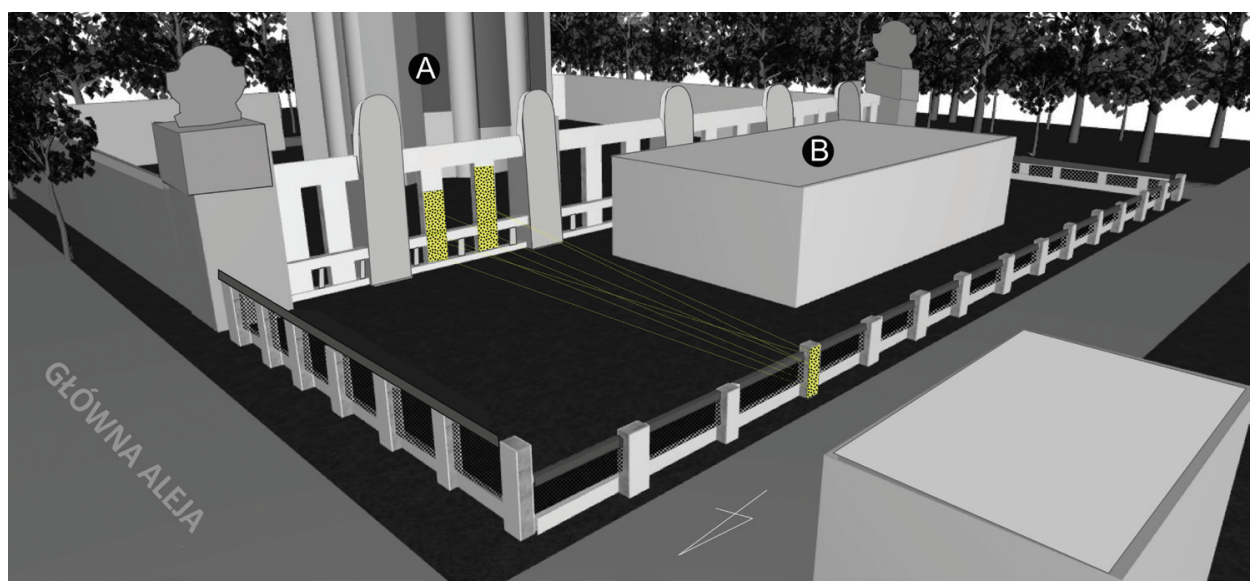

Ryc. 4. Cyfrowy model poglądowy ilustrujący rozmieszczenie śladów po ostrzałach na elementach kamiennych w obrębie kwatery „I” cmentarza żydowskiego w Łodzi (A - mauzoleum Poznańskich, B - mauzoleum Silbersteinów; kolorem oznaczono powierzchnie uszkodzone w wyniku ostrzału oraz przypuszczalne linie ostrzału). Opracowanie własne.
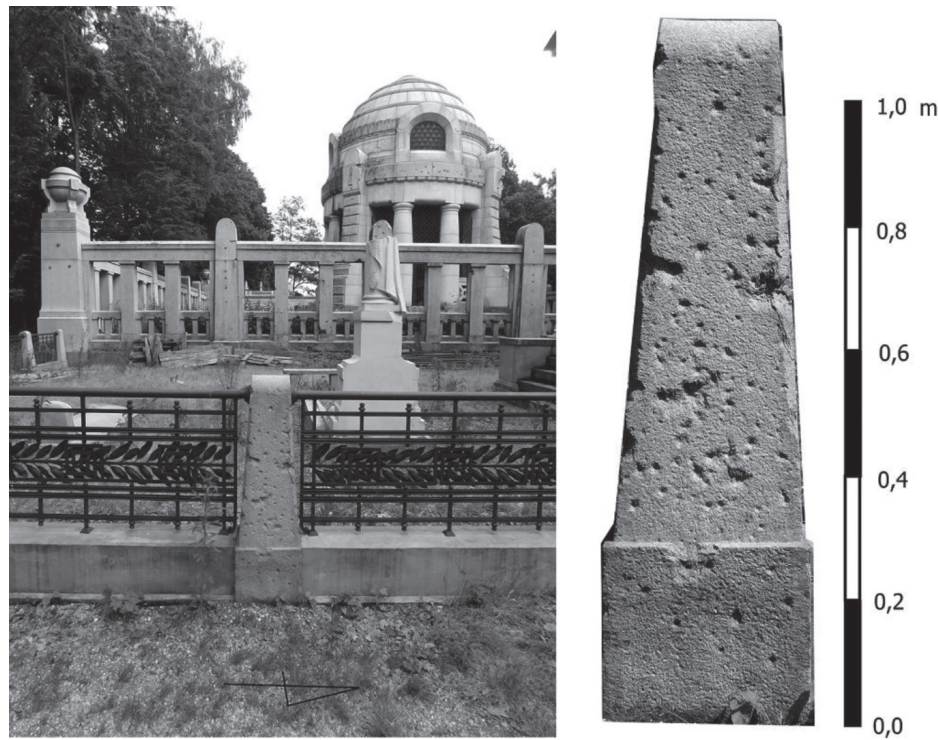

Ryc. 5. Ślady ostrzału na piaskowcowym słupku ogrodzenia otaczającego mauzoleum Silbersteinów. Fotografie i opracowanie własne. 
Z tym samym epizodem wojennym należałoby wiązać uszkodzenia znajdujące się w południowo-wschodniej części ogrodzenia pola grobowego Silbersteinów, na kolumnie stanowiącej jednocześnie słup graniczny pola grobowego Poznańskich (ryc. 6). Układ zidentyfikowanych uszkodzeń sugeruje ostrzał od strony północno-zachodniej. Ślady takie zarejestrowano również na grobowcu znajdującym się w północno-wschodnim narożniku kwatery „M”. Uszkodzenia o proweniencji wojennej rozpoznane na jego powierzchni są ulokowane od strony wschodniej i północno-wschodniej (ryc. 7). Pojedyncze ślady ostrzałów widoczne są ponadto na znajdującym się w pobliżu grobowcu Ignacego Sachsa, w jego części dystalnej.
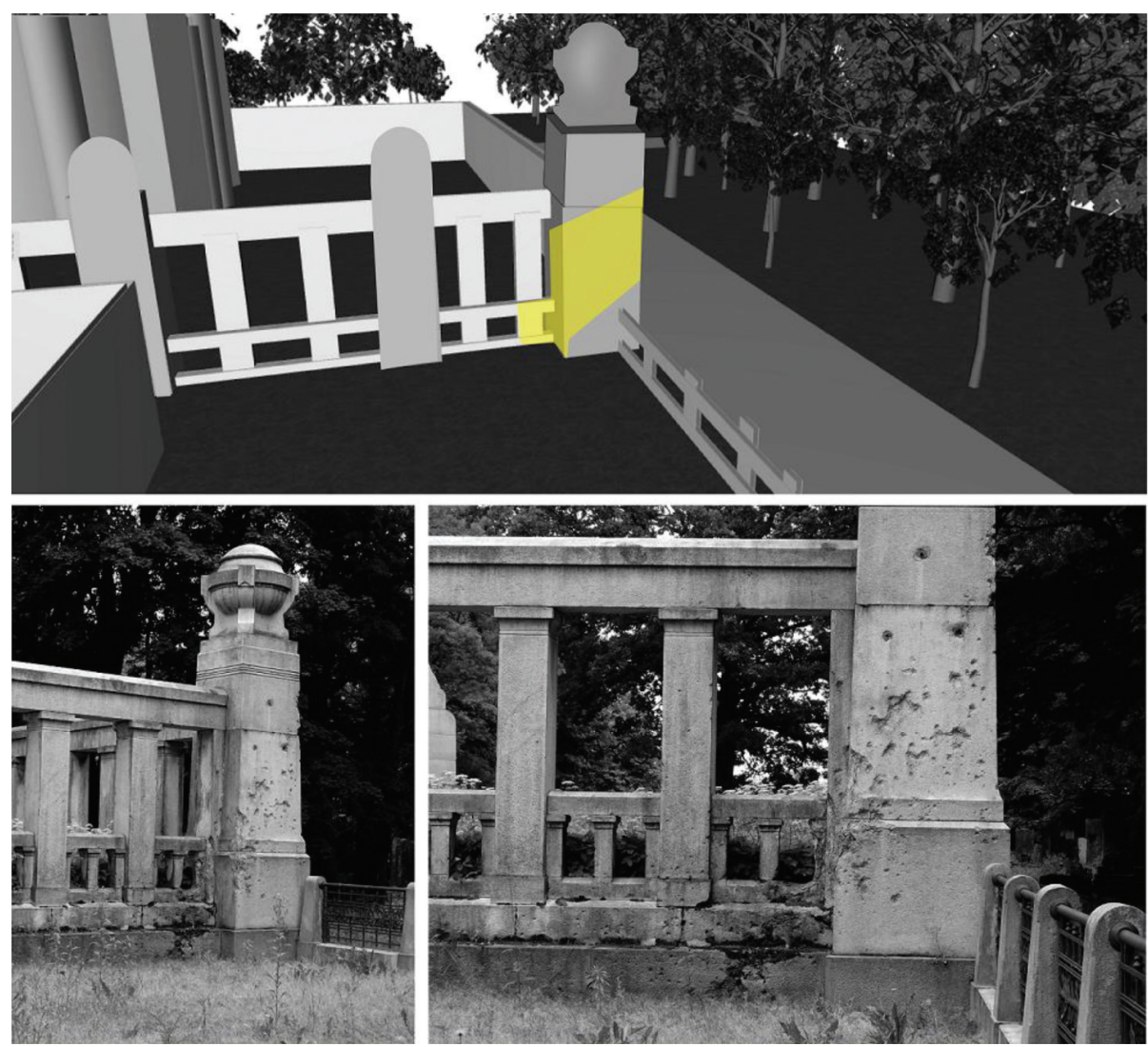

Ryc. 6. Powierzchnie uszkodzone w wyniku ostrzału, zarejestrowane w południowym narożniku ogrodzenia pola grobowego w kwaterze „I”. Fotografie i opracowanie własne.

Podczas gdy skutkiem Wielkiej Wojny były przede wszystkim materialne zniszczenia struktury cmentarza, stanowiące pokłosie prowadzonych działań zbrojnych, w wyniku drugiej wojny światowej Nowy Cmentarz Żydowski w Łodzi stał się jednym z symboli martyrologii narodu żydowskiego. W jego przestrzeni 
doskonale czytelne są świadectwa Holokaustu, które omówione zostaną w tej części pracy.
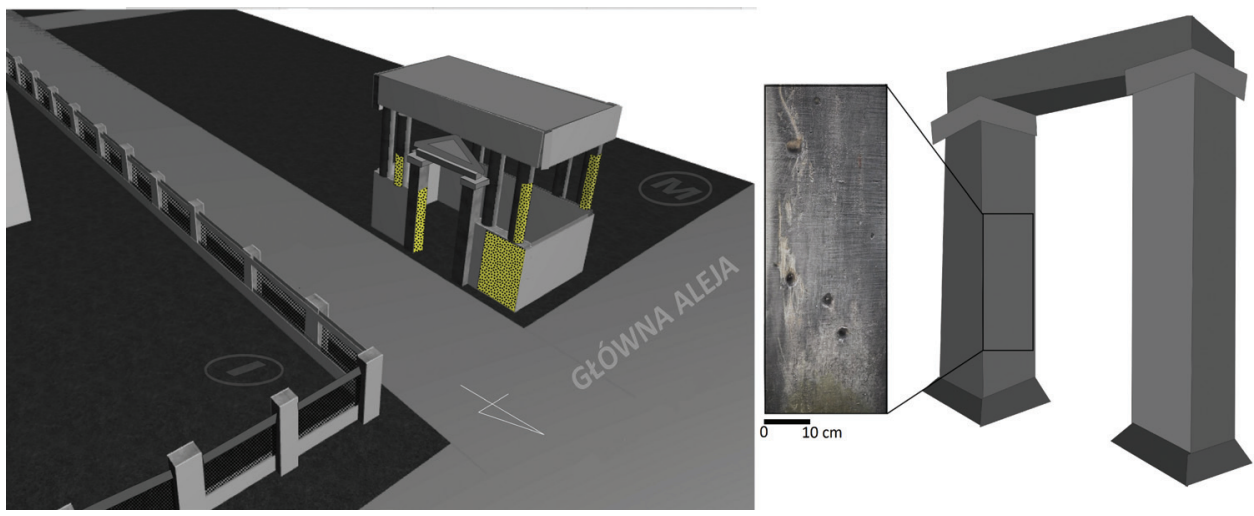

Ryc. 7. Powierzchnie uszkodzone w wyniku ostrzału, zarejestrowane na grobowcu znajdującym się w północno-wschodniej części kwatery „M”. Opracowanie własne.

W czasie drugiej wojny światowej niewykorzystane dotąd części cmentarzy wyznaniowych stawały się nekropoliami wojennymi, pozbawionymi w dużej mierze religijnego charakteru, a w pewien sposób również kulturowej ciągłości na skutek wykluczenia tradycyjnej sztuki sepulkralnej. Stawianie na mogiłach macew w postaci najczęściej hebrajskojęzycznych steli zostało przez Niemców zakazane. Na cmentarzu żydowskim w Łodzi podczas hitlerowskiej okupacji miejsca pochówku zmarłych były oznaczane przez rodziny metalowymi ramami łóżek lub słupkami ${ }^{33}$. Ponadto na oznaczanie grobów często brakowało czasu i sposobności, szczególnie w przypadku potajemnie organizowanego grzebania zwłok oraz licznych pogrzebów następujących w krótkich odstępach czasu. Na cmentarzu tym znajduje się tzw. Pole Gettowe, w którego obrębie pochowano około 45 tys. osób ${ }^{34}$. Dzięki zachowanej dokumentacji niektórym grobom w okresie powojennym przywrócono tożsamość, umieszczając na nich tablice z nazwiskami lub znacząc miejsca pochówków ujednoliconymi obramieniami betonowymi, nadającymi wizualnie tym kwaterom charakter cmentarza wojennego, którym de facto jest ta część nekropolii (chociaż nie została tak opisana w oficjalnych dokumentacjach).

${ }^{33}$ Por. E. Wiatr: Historia cmentarza..., s. 24.

${ }^{34}$ W Łodzi w latach 1940-1944 funkcjonowało Litzmannstadt Getto, zorganizowane przez Niemców w dzielnicach Bałuty i Stare Miasto, gdzie na obszarze 4,13 km² w czerwcu 1940 r. zamknięto 160 tys. Żydów. Łącznie w czasie drugiej wojny światowej przez getto przeszło ok. 200 tys. osób, z czego ok. 45 tys., zmarłych w wyniku głodu i chorób oraz pomordowanych, pochowano na Nowym Cmentarzu Żydowskim; por. J. Baranowski: Litzmannstadt Getto 1940-1944. W: Żydzi łódzcy. Red. A. Machejek. Łódź 2015, s. 90-99. 

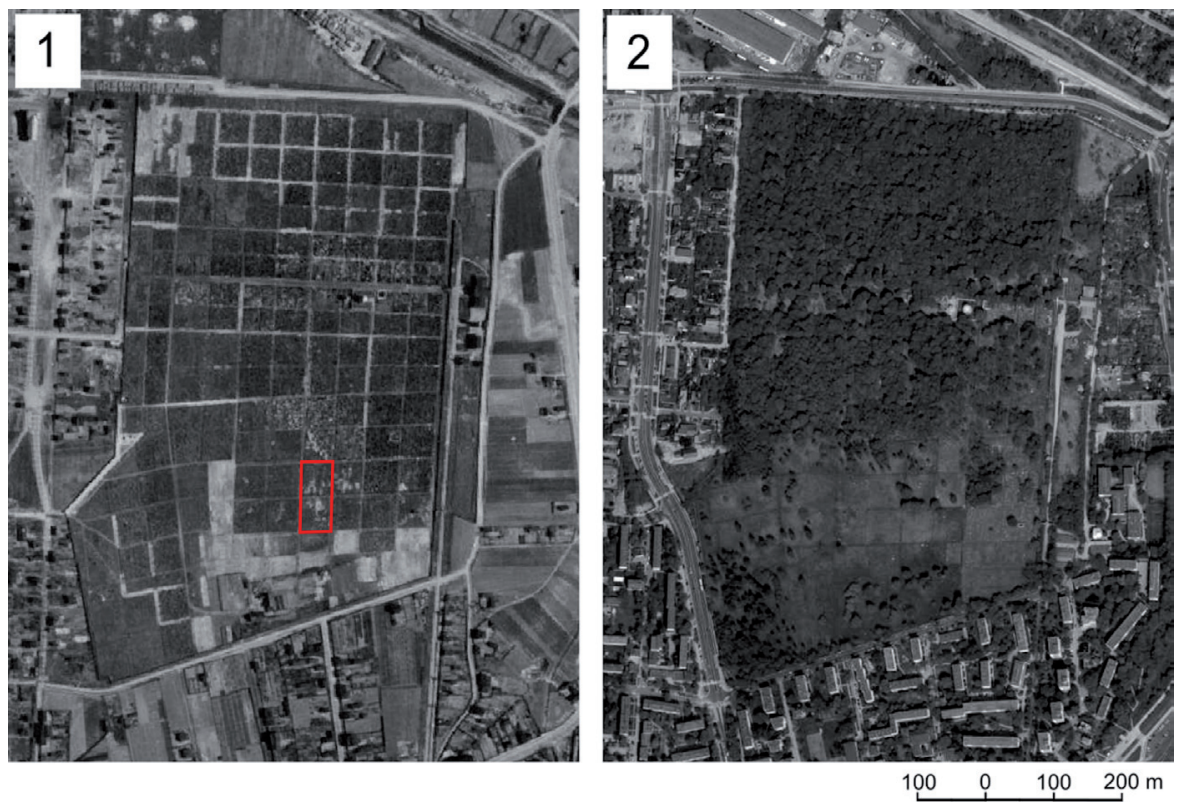

Ryc. 8. Pole Gettowe na Nowym Cmentarzu Żydowskim w Łodzi jako element krajobrazu konfliktu w ujęciu frozen palimpsest: 1 - zdjęcie lotnicze cmentarza z maja 1942 roku (czerwona ramka - przybliżona, prawdopodobna lokalizacja pochówków Romów), 2 - współczesna ortofotomapa. Źródła: Zdjęcie lotnicze 1:19 000, M. - Bl. 4282/15, 1942, Deutsches Bundesarchiv (licence: CC-BY-SA-3.0 Germany). Dostępne w Internecie: http://gis2.mapa.lodz.pl/historyczna_1942/default.aspx [data dostępu: 11.05.2019]; ortofotomapa - www.geoportal.gov.pl.

W obrębie Pola Gettowego poza tysiącami pojedynczych grobów znajdują się również mogiły zbiorowe, których lokalizacje do dzisiaj nie zostały jednoznacznie ustalone. Jest tak między innymi w przypadku masowego grobu około 613 osób narodowości romskiej (według źródeł w czasie epidemii tyfusu plamistego w Zigeunerlager w Litzmannstadt zmarło na przełomie 1941 i 1942 roku 719 Romów ${ }^{35}$ ). Mogiła o przybliżonej powierzchni $300 \mathrm{~m}^{2}$ znajduje się prawdopodobnie w kwaterze P-IV lub P-V Pola Gettowego ${ }^{36}$. Według danych z Kroniki getta łódzkiego... w grudniu 1942 roku pochowano tam 400 osób ${ }^{37}$. Na zdjęciu lotniczym wykonanym w maju 1942 roku w miejscu prawdopodobnej lokalizacji mogiły widoczne są obszerne naruszenia struktury gruntu, które można interpretować jako dokonane niewiele wcześniej pochówki (zob. zdjęcie lotnicze ryc. 8$)$.

${ }^{35}$ Por. J. Baranowski: The Gypsy Camp in Łódź 1941-1942. Łódź 2003, s. 34.

${ }^{36}$ Zob. I. Kersz: Szkice z dziejów..., s. 67; J. Podolska: The Jewish Cemetery in Łódź. Łódź 2010, s. 101.

${ }^{37}$ Por. Kronika getta łódzkiego/Litzmannstadt Getto 1941-1944. Red. J. Baranowski, S. Feuchert. T. 2: 1942. Łódź 2009, s. 3. 
Na cmentarzu żydowskim w Łodzi wyróżniono także inne elementy obecnej tkanki obiektu, które powstały w czasie drugiej wojny światowej i które można zaklasyfikować jako składowe drugowojennego krajobrazu konfliktu, a przede wszystkim świadectwa Zagłady. Należy do nich między innymi sześć dołów zlokalizowanych przy południowym murze cmentarza, po jego wewnętrznej stronie. Są to tzw. doły śmierci, które nie zostały nigdy wykorzystane. Wykopali je więźniowie Litzmannstadt Ghetto po jego likwidacji. Wówczas naziści pozostawili na terenie getta około 830 osób, które miały zająć się pracami porządkowymi (członkowie tzw. Aufräumungskommando). Rozkaz wykopania własnych grobów Żydzi otrzymali 10 stycznia 1945 roku. W wyznaczonym dniu (18 stycznia) zgłosiło się jedynie $20-26$ osób, jak podaje Ewa Wiatr ${ }^{38}$. Nazajutrz druga wojna światowa zakończyła się dla Łodzi, a doły pozostały niemym świadectwem Zagłady.

Tak zwane doły śmierci zilustrowano, wyizolowując je z obszaru cmentarza na wizualizacjach przestrzennych w postaci trójwymiarowych modeli (ryc. 9).
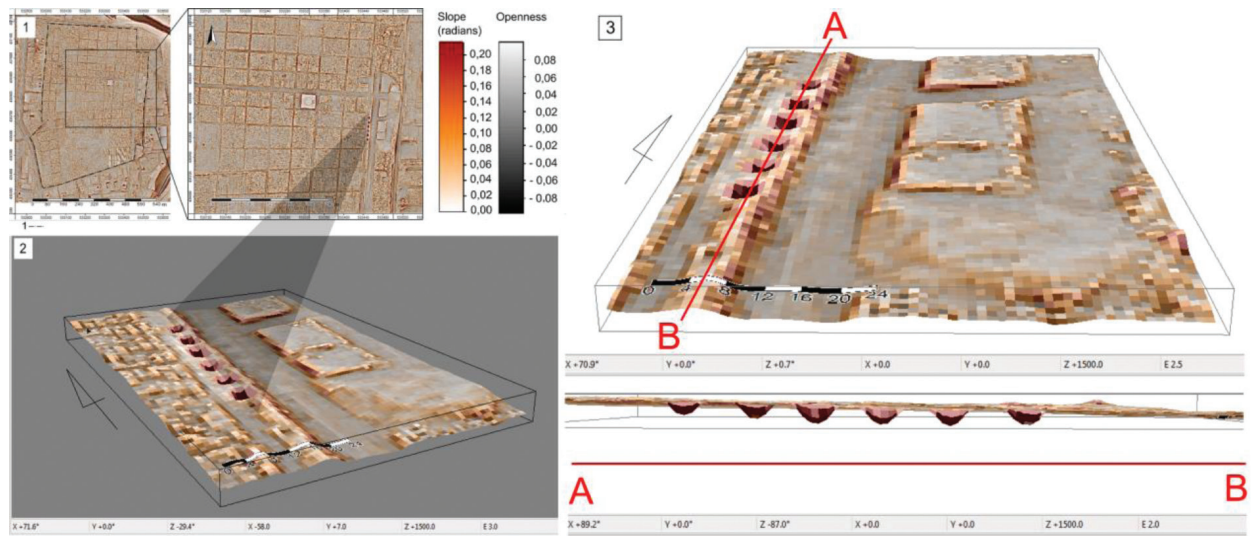

Ryc. 9. Wizualizacja ukształtowania powierzchni Nowego Cmentarza Żydowskiego w Łodzi (1); model 3D części cmentarza z tzw. dołami śmierci (2) (agregacja punktów w obrębie modelu 2,5); przekrój przez zinwentaryzowane elementy (3) (agregacja punktów 2,0). Opracowanie własne na podstawie arkusza danych NMT: M-34-3-D-b-2-4-3-4 pozyskanych z GUGiK, wykonanie nalotu: 2015 rok.

Obiekty te zachowano w obrębie założenia cmentarnego jako symbol mordów dokonywanych przez nazistów na ludności żydowskiej w czasie drugiej wojny światowej. Dzisiaj widocznych jest ich sześć, ale na przykład według Izaaka Kersza $^{39}$ oraz Ewy Wiatr ${ }^{40}$ wykopanych zostało dziewięć takich grobów. Poza dokonaniem prospekcji terenowej zinwentaryzowano je komputerowo za po-

\footnotetext{
38 Por. E. Wiatr: Historia cmentarza..., s. 27.

39 Por. I. Kersz: Szkice z dziejów..., s. 66.

${ }^{40}$ Por. E. Wiatr: Historia cmentarza..., s. 27.
} 
mocą przetwarzania danych pomiarowych numerycznego modelu terenu (format ASCII XYZ). Wykorzystano moduł modelowania obrazu morfologicznego (Morphology Method) - nachylenia stoków (LiDAR slope map). Zastosowana została analiza otwartości topograficznej (openness) podkreślająca punkty o silnych wahaniach kątowych w ukształtowaniu powierzchni terenu (wyniesień i obniżeń). Metoda ta pozwala uniknąć niedociągnięć (braków szczegółów ukształtowania terenu) związanych z kątem padania promieni słonecznych, co zdarza się $\mathrm{w}$ mapowaniu tradycyjną metodą cieniowania terenu (hillshading), w której światło pada $\mathrm{z}$ jednego punktu ${ }^{41}$, oraz łączących się $\mathrm{z}$ wadami obrazowania (na przykład przesunięć w poziomie), które mogą występować także $\mathrm{w}$ mapowaniu $\mathrm{z}$ wykorzystaniem sky-view factor ${ }^{42}$. Bardzo dobra czytelność tych elementów krajobrazu konfliktu w terenie i na obrazie morfometrycznym wynika również z prac konserwatorskich dokonywanych w obrębie obiektów polegających na pogłębianiu wykopów w kilkuletnich odstępach ${ }^{43}$.

\section{Wnioski}

Przedstawione $\mathrm{w}$ artykule zagadnienia związane $\mathrm{z}$ rozszerzeniem analiz krajobrazu konfliktu unaoczniają w szczególności, że między innymi w obliczu niedostatku źródeł pisanych to identyfikowane krajobrazowe świadectwa przebiegu działań zbrojnych i Holokaustu stanowią uzupełnienie wiedzy o dziejach obiektów oraz dawnych wspólnot żydowskich, w tym zwłaszcza z okresu dramatycznych wydarzeń XX wieku. Cmentarze posiadają strukturę palimpsestów, w obrębie których identyfikować można elementy o różnej morfogenezie. Przykładowo w ramach nekropolii łódzkiej przenikają się dwie główne przestrzenie: jedna - będąca odbiciem przedwojennego i powojennego funkcjonowania społeczności żydowskiej, oraz druga - stanowiąca świadectwo wojennych losów nie tylko Żydów z Łodzi, ale także tysięcy wyznawców judaizmu z innych miejscowości i państw, którzy zamknięci zostali w latach 1940-1944 przez niemieckiego okupanta w Litzmannstadt Ghetto, czego najbardziej przejmującym dowodem jest tzw. Pole Gettowe.

Zaprezentowane studium przypadku dowodzi, że nawet podjęcie recepcji i analizy obiektu już tak dobrze poznanego, jak - będący drugą pod względem

${ }^{41}$ Por. R. Chen et al.: Detecting and Characterizing Active Thrust Fault and Deep-Seated Landslides in Dense Forest Areas of Southern Taiwan Using Airborne LiDAR DEM. "Remote Sensing" 2015, Vol. 7, s. 15451.

${ }^{42}$ Por. M. Doneus: Openness as Visualization Technique for Interpretative Mapping of Airborne Lidar Derived Digital Terrain Models. "Remote Sensing” 2013, Vol. 5, s. 6427-6442.

${ }^{43}$ Zob. J. Podolska: The Jewish Cemetery..., s. 106. 
wielkości nekropolią żydowską w Europie - Nowy Cmentarz Żydowski w Łodzi, poprzez reinterpretację jego przestrzeni $\mathrm{w}$ ramach koncepcji krajobrazu konfliktu, skutkuje sformułowaniem interesujących hipotez dotyczących wydarzeń mających miejsce w jego obrębie w czasie pierwszej i drugiej wojny światowej. Badania studialne przeprowadzone na terenie tego cmentarza - między innymi zgeneralizowana planigrafia uszkodzeń po ostrzałach widocznych na elementach kamiennych w kwaterach „I” oraz „M” - ukazują nowy sposób analizowania krajobrazu konfliktu. Wskazano podejście metodyczne obejmujące nie tylko dokonanie opisu fizykalnego zarejestrowanych elementów krajobrazu konfliktu, ale również przeprowadzenie analizy przestrzennej, mającej na celu przybliżenie rekonstrukcji zdarzeń, które miały tam miejsce. Cmentarz żydowski w Łodzi jest także przestrzenią, gdzie niektóre z elementów krajobrazu konfliktu, jak drugowojenne, niewykorzystane przez nazistów doły, są konserwowane jako nieme, materialne świadectwa Zagłady.

Jak zasygnalizowano $\mathrm{w}$ pracy, krajobraz konfliktu jest konstruktem badawczym, który należy rozpatrywać wielopłaszczyznowo. W przedstawionym studium przypadku wyróżniono wybrane materialne składowe krajobrazu konfliktu sensu stricto, na których skoncentrowano analizy szczegółowe, co natomiast nie wyklucza obecności w tej przestrzeni innych elementów, odnoszących się również do różnego rodzaju konfliktów o charakterze społecznym. Szeroki zakres problematyki, którą można poruszyć w ramach studiów nad funkcjonowaniem żydowskich obiektów religijnych w kontekście krajobrazu konfliktu, stanowi przesłankę do badań nad dziedzictwem, o którym nadal nie wiemy jeszcze wszystkiego. Skłania także do reinterpretacji przestrzeni względnie dobrze rozpoznanej celem poszukiwania informacji uzupełniających naszą wiedzę między innymi na temat przebiegu konfliktów zbrojnych i ich wpływu na dziedzictwo kulturowe, przebiegu oraz świadectw Zagłady, powojennej dewastacji i profanacji obiektów.

\section{Bibliografia}

Archeologia totalitaryzmu. Ślady represji 1939-1956. Red. O. Ławrynowicz, J. Żelazko. Łódź 2015.

Arnold S.: Geografia historyczna Polski. Warszawa 1951.

Bailey G.: Time Perspectives, Palimpsests and the Archaeology of Time. "Journal of Anthropological Archaeology" 2007, Vol. 26, s. 198-223.

Baksik Ł.: Macewy codziennego użytku. Wołowiec 2012.

Banaszek Ł.: Badania archeologiczne w ramach projektu „Sztutowo czy Stutthof? Oswajanie krajobrazu kulturowego". W: Sztutowo czy Stutthof? Oswajanie krajobrazu kulturowego. Red. Ł. Banaszek, M. Wosińska. Poznań-Sztutowo 2011, s. 27-31. 
Baranowski J.: Litzmannstadt Getto 1940-1944. W: Żydzi łódzcy. Red. A. Machejek. Łódź 2015, s. 85-101.

Baranowski J.: The Gypsy Camp in Łódź 1941-1942. Łódź 2003.

Bielawski K.: Zagłada cmentarzy żydowskich. Warszawa 2020.

Budyta-Budzyńska M.: Socjologia narodu i konfliktów etnicznych. Warszawa 2010.

Chen R. et al.: Detecting and Characterizing Active Thrust Fault and Deep-Seated Landslides in Dense Forest Areas of Southern Taiwan Using Airborne LiDAR DEM. "Remote Sensing" 2015, Vol. 7, s. 15443-15466.

Coleman P.T. et al.: Navigating the Landscape of Conflict: Applications of Dynamical Systems Theory to Addressing Protracted Conflict. In: The Non-linearity of Peace Processes. Theory and Practice of Systemic Conflict Transformation. Eds. D. Körppen, N. Ropers, H.J. Giessmann. Opladen 2011, s. 39-56.

Colls C.S.: Holocaust Archaeologies. Approaches and Future Directions. London 2015.

Colls C.S.: Holocaust Archaeology: Archaeological Approaches to Landscapes of Nazi Genocide and Persecution. "Journal of Conflict Archaeology" 2012, Vol. 7, Issue 2, s. $70-104$.

Crawford O.G.S.: Archaeology in the Field. London 1953.

Creighton O.H., Wright D.W.: The Anarchy. War and Status in 12th-Century Landscapes of Conflict. Liverpool 2016.

Dahrendorf R.: Teoria konfliktu w społeczeństwie przemysłowym. W: Elementy teorii socjologicznych. Red. W. Dereczyński, A. Jasińska-Kania, J. Szacki. Warszawa 1975, s. $429-463$.

Delle J.A., Heaton P.: The Hector Backbone: A Quiescent Landscape of Conflict. "Historical Archaeology" 2003, Vol. 37, Issue 3, s. 93-110.

Domańska E.: Cmentarze jako przedmiot historii ratowniczej (rescue history). W: Ziemia skrywa kości. Zapomniane krajobrazy pamięci - cmentarze protestanckie w Wielkopolsce po 1945 roku. Red. J. Kołacki, I. Skórzyńska. Poznań 2017, s. 33-45.

Domańska E.: Gleba cmentarna jako dziedzictwo. W: Dziedzictwo we współczesnym świecie: kultura, natura, człowiek. Red. A. Marciniak, M. Pawleta, K. Kajda. Kraków 2018, s. 73-87.

Doneus M.: Openness as Visualization Technique for Interpretative Mapping of Airborne Lidar Derived Digital Terrain Models. "Remote Sensing” 2013, Vol. 5, s. 6427-6442.

Geoportal Ortofotomapa. Dostępne w Internecie: www.geoportal.gov.pl [data dostępu: 11.05.2019].

Jensen D., Baird T., Blank G.: New Landscapes of Conflict: Land-use Competition at the Urban-rural Fringe. "Landscape Research" 2019, Vol. 44, Issue 4, s. 418-429.

Karsvall O.: Retrogressiv metod. En översikt med exempel från historisk geografi och agrarhistoria. „Historisk Tidskrift” 2013, 133 (3), s. 411-435.

Katyń w świetle badań terenowych 1994-1995. Red. M. Głosek. Toruń 2003.

Kersz I.: Szkice z dziejów Gminy Żydowskiej oraz cmentarza w Łodzi. Łódź 1996.

Kobiałka D., Frąckowiak M., Kajda K.: Tree Memories of the Second World War: a Case Study of Common Beeches from Chycina, Poland. "Antiquity" 2015, Vol. 89, Issue 345, s. 683-696.

Kola A.: Archeologia zbrodni. Oficerowie polscy na cmentarzu ofiar NKWD w Charkowie. Toruń 2005. 
Kronika getta łódzkiego/Litzmannstadt Getto 1941-1944. Red. J. Baranowski, S. Feuchert. T. 2: 1942. Łódź 2009.

Majewska A.: Continuity and Decline. Temporal Expression of Denominational Cemeteries in Contemporary Times. „Acta Universitatis Lodziensis. Folia Archaeologica” 2019, nr 34, s. 71-96.

Majewska A.: Jewish Sepulchral Heritage in Silesian Voivodeship Divided by the Borders. Similarities and Differences. In: "Region and Regionalism". No 13, Vol. 2. Eds. K. Heffner, B. Solga. Łódź-Opole 2017, s. 147-167.

Monumenta et Memoria. Cmentarz żydowski w Łodzi. Red. L. Hońdo. Łódź 2016.

Moshenska G.: Resonant Materiality and Violent Remembering: Archaeology, Memory and Bombing. "International Journal of Heritage Studies" 2009, Vol. 15, Issue 1, s. $44-56$.

Nolan T.J.: Geographic Information Science as a Method of Integrating History and Archaeology for Battlefield Interpretation. "Journal of Conflict Archaeology" 2009, Vol. 5, Issue 1, s. 81-104.

Nowy Cmentarz Żydowski. Dostępne w Internecie: http://fotopolska.eu/Lodz/b37432, Nowy_cmentarz_zydowski.html?f=1064073-foto [data dostępu: 11.05.2019].

Numeryczny Model Terenu (NMT), arkusz danych: M-34-3-D-b-2-4-3-4, Centralny Ośrodek Dokumentacji Geodezyjnej i Kartograficznej, Warszawa 2017.

Passmore D.G., Harrison S., Tunwell D.C.: Second World War Conflict Archaeology in the Forests of North-west Europe. "Antiquity" 2014, Vol. 88, Issue 342, s. 1275-1290.

Pholsena V.: A Social Reading of a Post-Conflict Landscape: Route 9 in Southern Laos. In: Interactions with a Violent Past. Reading Post-Conflict Landscapes in Cambodia, Laos and Vietnam. Eds. V. Pholsena, O. Tappe. Singapore 2013, s. 157-185.

Podolska J.: The Jewish Cemetery in Łódź. Łódź 2010.

Podolska J., Walicki J.: A Guide to the Jewish Cemetery in Łódź. Łódź 1997.

Rzepkowski A.: Ludność Łodzi w okresie I wojny światowej. Łódź 2013.

Saunders N.J.: Killing Time. Archaeology and the First World War. Stroud 2007.

Saunders N.J.: Trench Art: A Brief History and Guide. Philadelphia 2001.

Saunders N.J. et al.: Conflict Landscapes of the Soča/Isonzo Front, 1915-2013: Archaeological-Anthropological Evaluation of the Soča Valley, Slovenia. „Arheo. Arheološka obvestila. Glasilo Slovenskega arheološkega društva” 2013, 30, s. 47-66.

Saunders N.J., Faulkner N.: Fire on the Desert: Conflict Archaeology and the Great Arab Revolt in Jordan, 1916-18. "Antiquity" 2010, Vol. 84, Issue 324, s. 514-527.

Schackel P.A.: Archaeology, Memory, and Landscapes of Conflicts. "Historical Archaeology" 2003, Vol. 37, Issue 3, s. 3-13.

Schofield J.: Combat Archaeology: Material Culture and Modern Conflict. London 2005.

Stawiszyńska A.: Łódź w latach I wojny światowej. Oświęcim 2016.

Szacki J.: Dylematy historiografii idei oraz inne szkice i studia. Warszawa 1991.

Wejland A.P.: Pojęcia podstawowe. W: Miejsca pamięci i miejsca zapomnienia. Interdyscyplinarne badania na Jurze Krakowsko-Częstochowskiej. Raport z badań. T. 1: Wprowadzenie metodologiczne. Red. A.P. Wejland, O. Ławrynowicz. Łódź 2016, s. 34-45.

Wiatr E.: Historia cmentarza. W: Monumenta et Memoria. Cmentarz żydowski w Łodzi. Red. L. Hońdo. Łódź 2016, s. 9-34.

Wojalski M.Z.: Cmentarz żydowski w Łodzi. Łódź 2000. 
Anna Majewska - mgr, doktorantka w Katedrze Geografii Politycznej, Historycznej i Studiów Regionalnych Wydziału Nauk Geograficznych Uniwersytetu Łódzkiego. Jej zainteresowania badawcze koncentrują się na przemianach krajobrazu kulturowego, w szczególności dotyczących żydowskich obiektów religijnych oraz struktur wyludnionych jednostek osadniczych. Archeolog i geograf. Jej praca magisterska na temat żydowskiego dziedzictwa religijnego w przestrzeni województwa śląskiego została nagrodzona w kilku konkursach, w tym w prestiżowym Konkursie im. Majera Bałabana organizowanym przez Żydowski Instytut Historyczny w Warszawie. 